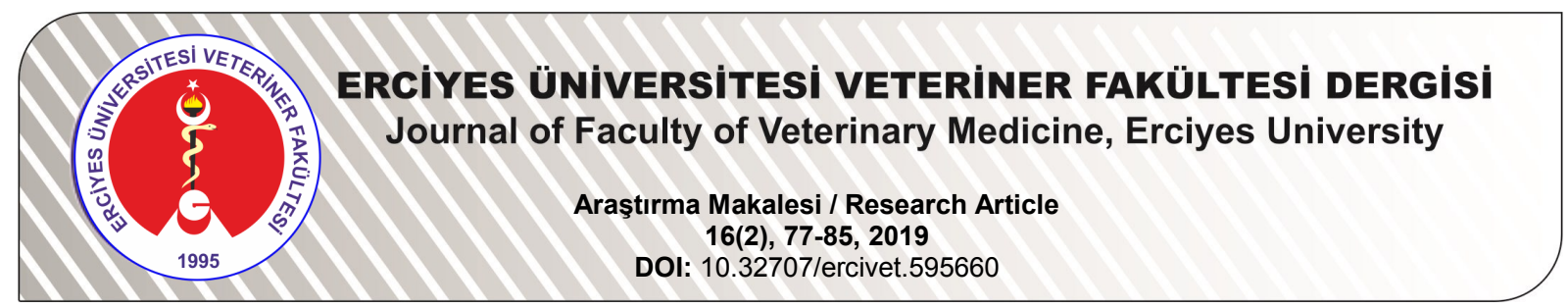

\title{
Adaptation of Attitude Scale towards the Treatment of Animals to Turkish: A Validity and Reliability Study
}

\author{
Şeyda GÜL, Esra ÖZAY KÖSE
}

Ataturk University, Kazim Karabekir Faculty of Education, Department of Biology Education, Erzurum-TURKEY

\begin{abstract}
Corresponding author: Şeyda GÜL; E-mail: seydagul@atauni.edu.tr; ORCID:0000-0003-4005-2158
How to cite: Gül Ş, Özay Köse E. Adaptation of attitude scale towards the treatment of animals to Turkish: A validity and reliability study. Erciyes Üniv Vet Fak Derg 2019; 16(2): 77-85.
\end{abstract}

\begin{abstract}
Summary: The aim of this study is to adapt to Turkish the Attitude Scale towards the Treatment of Animals (ASTA). At the first stage, the linguistic validity of the translated scale was examined by utilizing the data obtained from 4 expert academicians and 24 university students. Upon satisfaction of the linguistic validity requirements, item analysis, exploratory factor analysis and confirmatory factor analysis were performed, respectively. For this aim, the five-point Likert Scale composed of 30 items was administered to a total of 218 teachers to be enrolled in prospective biology and science departments of Kazim Karabekir Faculty of Education in Ataturk University. After item analysis and Explanatory Factor Analysis (EFA) was performed, it was ascertained that the scale consisted of 19 items and three factors (pets, pests and profit). In order to analyse the triple factorial structure of the ASTA, Confirmatory Factor Analysis (CFA) was carried out and the findings indicated that 19-item scale resulting in three factors is consistent and compatible with the data. Cronbach's Alpha for the overall scale was calculated as 0.827 . As a result, the findings of this study indicate that the Turkish ASTA is a valid and reliable scale for Turkish students.
\end{abstract}

Key words: Animals treatment, attitude scale, reliability, validity

Hayvan Müdahalesine Yönelik Tutum Ölçeğinin Türkçe' ye Uyarlanması: Geçerlik ve Güvenirlik Çalışması Özet: Bu çalışmanın amacı "Hayvan Müdahalesine Yönelik Tutum Ölçeği”" ni Türkçe' ye uyarlamaktır. Illk aşamada, dört uzman akademisyen ve 24 öğrenciden elde edilen veriler kullanılarak ölçeğin dil geçerliliği sağlanmıştır. Dil geçerliği sağlandıktan sonra sırasıyla madde analizi, açıklayıcı faktör analizi ve doğrulayıcı faktör analizi yapılmıştır. Bu amaçla, Atatürk Üniversitesi Kazım Karabekir Eğitim Fakültesi'ne devam eden toplam 218 biyoloji ve fen bilgisi öğretmen adaylarına 30 maddeden oluşan beşli Likert ölçek uygulanmıştır. Madde analizi ve Açıklayıcı Faktör Analizi (AFA) yapıldıktan sonra, ölçeğin 19 maddelik üç faktörden (evcil hayvanlar, zararlılar ve fayda) oluştuğu tespit edildi. Ölçeğin üçlü faktöriyel yapısını analiz etmek için Doğrulayıcı Faktör Analizi (DFA) yapıımıştır ve elde edilen bulgular, 19 maddelik üç faktörlü bu yapının tutarlı ve veriyle uyumlu olduğunu ortaya koymuştur. Ölçeğin geneline ait Cronbach Alpha katsayısı ise 0.827 olarak hesaplanmıştır. Sonuç olarak, bu çalışmanın bulguları, ölçeğin Türkçe formunun geçerli ve güvenilir bir ölçek olduğunu ortaya koymaktadır.

Anahtar kelimeler: Hayvan müdahalesi, geçerlik, güvenirlik, tutum ölçeği

\section{Introduction}

Animals play an important role in the cultural, political and social arena of modern societies (40). Therefore, animal welfare and treatment of animals are becoming increasingly important in the world from a social, political, ethical and scientific viewpoint $(14,24)$. Additionally, governments are lobbying to change or create laws to protect animals (40). In perspective, four approaches can be distinguished regarding the obligations that we, humans, have with respect to animals (34): (a) Utilitarianism, which is based on the principle of equality between species. (b) Animal rights where the principle of equality is accepted but, unlike utilitarianism, it never justifies the slaughtering of one individual for the benefit of another. (c) Integrity of the species. It is not just individuals that must be

Geliş Tarihi/Submission Date : 21.03.2017 Kabul Tarihi/Accepted Date : 18.05 .2018 morally respected but rather this perspective values the existence of the species over the welfare of each individual. (d) The viewpoint that is known as agentcentred, which assumes that we must have a moral attitude towards animals as an indirect agent over our own morality towards our species $(24,31,32,34,37)$.

Recently, people are getting more concerned about the welfare of animals and the way animals are being treated by humans (43). The researches indicated that the general public is not only concerned about the welfare of laboratory animals or animals used for commercial purposes, but also about the welfare of companion animals. Our moral attitude towards animals changed over the last century, but interestingly, this change can be recognized in opposite directions. On the one hand, animals become more and more instrumental. They often function as mere instruments in industrialized processes. On the other hand, 
animals get a stronger position in society than ever before (43). Animal research has played a central role in psychology, yet its clinical value and ethical propriety have recently come under attack. Indeed, research on animals has played a central role in psychology throughout most of the 20th century. Nevertheless, whether for reasons of cost, increased regulation, animal rights, or other factors, animal research does seem to be on the decline. During the past 20 years, the number of animals used in research worldwide has fallen by an estimated $30-50 \%(29,33)$.

The subject of animal welfare and animal treatment has developed rapidly as a scientific discipline since the 1980s, but its ethical basis existed long before (5). Science has showed that animal care is important to their physiology, their immune system, etc., so as Broom (4) stated we see the need to move this education scientific knowledge and the changes in attitudes of people with animals. In addition, it has been suggested that animal-directed empathy may generalize to human-directed empathy. Hence, humane education is being posited as one particularly effective mechanism whereby a lack of humandirected empathy may be remedied by teaching animal welfare appropriate attitudes (40).

Factors known to affect attitudes towards animals include personality, gender and sex role orientation, religious and/or political stance, ethical ideology, companion animal ownership, and other demographic variables (40). Many researches on this subject have adopted qualitative methodologies and therefore have small samples, whilst others with a more quantitative focus have only drawn samples from very narrow sections of the population such as highschool or university students (41). However, due to the increasing awareness of the importance of animals in human life, researchers have developed a variety of instruments designed to measure aspects of our relationships with other species (18). The majority of the scales they located, however, assessed aspects of relationships with pets, and much less attention has been given to assessing individual differences in attitudes toward the use of other species $(18,44)$. A lot of surveys in literature were conducted to elucidate peoples' attitudes of these issues $(17,41)$. However, a comprehensive research about treatment of animal related to pets, pest and profit in Turkey was not implemented owing to the lack of a scale towards treatment of animal. Therefore, it may be said that there is a need to develop a scale towards treatment of animal. For this reason, this study has adopted a scale towards the treatment of animals included in sub factors (A) pet, (B) pest, and (C) profit.

\section{Materials and Methods}

In this study, quantitative research paradigm was utilized and planned as a scale adaptation study based on a survey method (9). In survey research, the researcher selects a sample of respondents from a target population and administers a questionnaire or conducts interviews to collect information on variables of interest. Surveys are used to learn about people's attitudes, beliefs, values, demographics, behavior, opinions, habits, desires ideas and other type information (26).

\section{Sample}

This study was totally carried out with 218 prospective teachers attending the departments of biology (18 male, 46 female) and science (36 male, 118 female) teacher education of Kazim Karabekir Faculty of Education in Ataturk University during the academic year of 2016-2017. In determining the sample, the rule of thumb according to Bryman and Cramer (6) "the sample should be in number at least five times as many as the item number in the scale". While choosing the sample, appropriate sampling method was used (9). The criterion behind this choice is the fact that these students were familiar to animals and other living organisms. In this perspective, item analysis, Explanatory Factor Analysis (EFA), Confirmatory Factor Analysis (CFA) and reliability analyzes were done.

\section{Original data collection tool}

Attitude Scale towards the Treatment of Animals [ASTA] is a Likert scale developed by Taylor and Signal (41). Actually, Taylor and Signal (41)' scale were developed by Herzog, Betchart and Pittman (18) as Animal Attitude Scale (AAS). According to Taylor and Signal (41), because of the fact that the AAS did not discriminate between categories of animals, that is, pets, pests, and commercially valued species, they, therefore, conducted a study to develop a scale aimed at isolating differences in attitudes towards animals across three different categories: (A) pet (companion animal), (B) pest, and (C) profit/utility animals.

The ASTA with a 30-item consists of three subscales, namely Pets (10 items), Pests (10 items) and Profit (10 items). The scale was prepared in 5-point Likert type $(1=$ Not true, $2=$ slightly true, $3=$ moderately true, $4=$ mostly true, $5=$ completely true).

\section{Scale development process}

The purpose of this study was to adapt "Attitude Scale towards the Treatment of Animals [ASTA]" developed by Taylor and Signal (41) to Turkish as "Attitude Scale towards the Treatment of Animals [ASTA]" and investigate the validity and reliability of ASTA. The Turkish adaptation of ASTA was done after necessary permissions from the author. After obtaining necessary permission, Turkish draft form of 
the scale was created by the researchers for scale's adaptation to Turkish. The process of adaptation is an attempt to produce equivalency between the source and the target based on the content (1). Therefore, in this process, the designs of forwardtranslation and back-translation were employed to provide the linguistic validity. In forward-translation, the scale is adapted from the original language into the target language by one or more translators. The adequateness of the translation is checked by a translator or by a group of translators. If necessary, corrections on the translation can be carried out at this stage. The fact that experts can make comparisons between the source language and the target language directly in forward-translation, and that small groups are sufficient for the validity of expert judgments can be listed as the advantages of the technique (3). In addition, it can be said that the translation from source language to target language, which is known as back-translation, is the most important point of adaptation study (42). In backtranslation, the scale is adapted from the source language into the target language by one or more translators. Then, one or more translators adapt the text back from the target language into the source language. The original and the back-translated texts are compared, and decisions are made on the equivalence. Efforts are made to ensure the equivalence of both texts (3). In this perspective, the scale was translated into both Turkish from its original form and from Turkish into English (back-translation) by researchers to provide the language validity. As known, back-translation is a method often considered best practice for questionnaire design and this method starts with a direct translation but adds some additional steps to assess the quality and equivalence of the translation. In essence, it involves a direct translation, followed by a second translation where an independent person translates the new version back into the source language. Comparisons are then made between the original and back-translated versions to identify discrepancies in the target instrument (30). Afterwards, scale was checked by totally 4 expert academicians from the department of English Language Education (2) and from the department of Turkish Language Education (2), independently. The experts were asked to score the items on three-point scale as "sufficient", "should be corrected", and "insufficient". After necessary changes and corrections according to the experts' opinions were done, the scale was administrated to totally 24 students (18 females, 6 males) attending to the department of English Language Education in Ataturk University in order to provide the linguistic equivalence through bilingual design. The results of analysis showed there was a high correlation between the pre and post applications. And then, scaling options to draft scale items and demographic data were added and the scale was prepared in 5-point Likert type (1= Strongly Disagree, 2= Disagree, 3= Neutral, 4= Agree, 5= Strongly Agree). The negatively-worded items were also reversed. After that, the item analysis, construct validity and reliability analysis of the draft scale were started. For this aim, it was administered to a sample of 218 students in total. The item-total correlation values were analyzed in item analysis. Additionally, Explanatory Factor Analysis (EFA) and Confirmatory Factor Analysis (CFA) were done for construct validity, and also Cronbach Alpha value was analyzed for reliability analysis. EFA is performed to explore the underlying factor structure of this instrument (38). Similarly, CFA is a sub-model of structural equation models (SEM); its mathematical principles and statistical procedures are all special applications of SEM, which enable the estimation and analysis of latent variables (10). If this EFA factor structure was the same as the original theoretical model, the CFA was applied to validate the theoretical structure of the ASTA empirically. If the EFA factor structure was different from the original theoretical model, the CFA

Table 1. Item-total correlations, mean, standard deviation of items in ASTA

\begin{tabular}{cccccccc}
\hline Item No & $\begin{array}{c}\text { Item-Total Cor- } \\
\text { relation }\end{array}$ & $\overline{\boldsymbol{x}}$ & $\mathbf{s}$ & Item No & $\begin{array}{c}\text { Item-Total Cor- } \\
\text { relation }\end{array}$ & $\overline{\boldsymbol{x}}$ & $\mathbf{s}$ \\
\hline $\mathbf{I}$ & 0.348 & 4.66 & 0.70 & $\mathbf{I 1 6}$ & 0.325 & 3.76 & 1.04 \\
$\mathbf{I}$ & 0.382 & 4.38 & 0.86 & $\mathbf{I 1 7}$ & $\mathbf{0 . 1 0 0}$ & 3.11 & 1.26 \\
$\mathbf{I}$ & 0.401 & 3.89 & 1.20 & $\mathbf{I 1 8}$ & $\mathbf{0 . 1 7 8}$ & 2.38 & 1.35 \\
$\mathbf{I}$ & $\mathbf{1}$ & 3.269 & 1.22 & $\mathbf{I 1 9}$ & $\mathbf{0 . 1 3 3}$ & 2.20 & 1.34 \\
$\mathbf{I 5}$ & 0.384 & 4.43 & 0.85 & $\mathbf{I 2 0}$ & $\mathbf{0 . 2 3 7}$ & 2.41 & 1.48 \\
$\mathbf{I 6}$ & 0.388 & 4.46 & 0.68 & $\mathbf{I 2 1}$ & 0.341 & 4.00 & 0.98 \\
$\mathbf{I 7}$ & 0.344 & 4.42 & 0.86 & $\mathbf{I 2 2}$ & 0.335 & 3.29 & 1.22 \\
$\mathbf{I 8}$ & 0.543 & 4.13 & 1.04 & $\mathbf{I 2 3}$ & 0.374 & 3.52 & 1.16 \\
$\mathbf{I 9}$ & 0.360 & 4.56 & 0.76 & $\mathbf{I 2 4}$ & $\mathbf{0 . 2 1 3}$ & 3.82 & 1.18 \\
$\mathbf{I 1 0}$ & 0.456 & 4.59 & 0.70 & $\mathbf{I 2 5}$ & $\mathbf{0 . 2 1 6}$ & 3.54 & 1.15 \\
$\mathbf{I 1 1}$ & 0.336 & 3.76 & 1.09 & $\mathbf{I 2 6}$ & 0.342 & 2.73 & 1.33 \\
$\mathbf{I 1 2}$ & 0.310 & 4.10 & 0.89 & $\mathbf{I 2 7}$ & $\mathbf{0 . 2 3 2}$ & 3.60 & 1.11 \\
$\mathbf{I 1 3}$ & 0.373 & 4.14 & 0.87 & $\mathbf{I 2 8}$ & $\mathbf{0 . 1 9 0}$ & 3.62 & 1.10 \\
$\mathbf{I 1 4}$ & 0.378 & 3.89 & 1.12 & $\mathbf{I 2 9}$ & $\mathbf{0 . 2 5 1}$ & 3.91 & 1.01 \\
$\mathbf{I 1 5}$ & 0.312 & 4.01 & 1.09 & $\mathbf{I 3 0}$ & $\mathbf{0 . 2 3 4}$ & 3.78 & 1.10 \\
\hline
\end{tabular}

$\bar{x}=$ mean,$\quad \mathrm{s}=$ standart deviation 
was applied to determine which model fitted the data best (23). Finally, SPSS 20.0 program was used for the EFA and reliability analyses, and LISREL 8.8 software was used for the CFA. After the analyses, the scale was finalized by interpreting the data.

\section{Results}

\section{The findings for linguistic validity}

As stated above, the process of cross-cultural adaptation tries to produce equivalency between source and target based on content. The assumption that is sometimes made is that this process will ensure retention of psychometric properties such as validity and reliability at an item and/or a scale level (1). In this study, linguistic equivalence of the Attitude Scale towards the Treatment of Animals [ASTA] was provided by using the designs of forward-translation and back-translation from bilingual designs. For this aim, the scale was administrated to 24 students (18 females, 6 males). As a result of correlation analysis, which was done for linguistic equivalence, it was determined that there was a high positive correlation

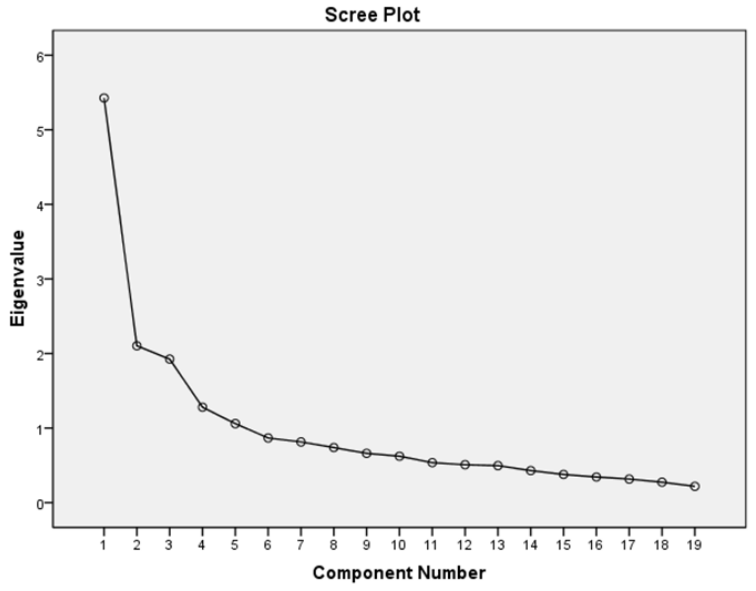

Figure 1. Graph of scree plot

$(r=0.808, \mathrm{P}<0.001)$ between the English form (source language) and Turkish form (Turkish language) of the scale. According to these results, it can be said that the scale has linguistic equivalence.

Table 2. Factor loadings of each ASTA item after varimax rotation

\begin{tabular}{|c|c|c|c|c|}
\hline \multirow[b]{2}{*}{$\begin{array}{l}\text { Item } \\
\text { no }\end{array}$} & \multirow[b]{2}{*}{ Item } & \multicolumn{3}{|c|}{ Factors } \\
\hline & & $\begin{array}{l}\text { Pets } \\
\text { (A) }\end{array}$ & $\begin{array}{l}\text { Pests } \\
\text { (B) }\end{array}$ & $\begin{array}{l}\text { Profit } \\
\text { (C) }\end{array}$ \\
\hline 17 & $\begin{array}{l}\text { Pets need to access fresh water and to a diet that maintains their full } \\
\text { health. }\end{array}$ & 0.722 & & \\
\hline 19 & Pets should be provided the shelter or a comfortable living area. & 0.699 & & \\
\hline 16 & Pets should have a regular health check. & 0.689 & & \\
\hline 11 & Sick animals have a right to veterinary care. & 0.680 & & \\
\hline 15 & All pets need to some attention every time. & 0.676 & & \\
\hline $\mathrm{I} 10$ & Pets have the right to freedom from pain, injury or disease. & 0.674 & & \\
\hline 12 & Pets have a right to live free from fear and distress. & 0.662 & & \\
\hline 18 & $\begin{array}{l}\text { I get concerned when my pet (or would if I had one) did not eat its } \\
\text { food. }\end{array}$ & 0.619 & & \\
\hline 13 & I think of my pet (or would if I had one) as a member of my family & 0.555 & & \\
\hline $\mid 15$ & $\begin{array}{l}\text { Pest species should have the freedom to express natural behaviors in } \\
\text { their living area. }\end{array}$ & & 0.758 & \\
\hline 114 & $\begin{array}{l}\text { Pest species have the right to live their lives free from fear and dis- } \\
\text { tress in their living area. }\end{array}$ & & 0.757 & \\
\hline $\mid 16$ & Pest species have the right to freedom from pain, injury or disease. & & 0.723 & \\
\hline 113 & $\begin{array}{l}\text { Pest species have the right to live their lives free of discomfort in their } \\
\text { living area. }\end{array}$ & & 0.694 & \\
\hline $\mid 11$ & $\begin{array}{l}\text { Pest species have the right to access fresh water and to a diet that } \\
\text { maintains their full health in their living area. }\end{array}$ & & 0.606 & \\
\hline 112 & $\begin{array}{l}\text { We should use more humane methods to deal with problematic pest } \\
\text { species. }\end{array}$ & & 0.589 & \\
\hline 122 & Live transport of animals is an acceptable source of income. & & & 0.829 \\
\hline 123 & It is acceptable to use animals for human profit. & & & 0.781 \\
\hline 126 & $\begin{array}{l}\text { It is acceptable to use animals to test products such as cosmetics and } \\
\text { household cleaners. }\end{array}$ & & & 0.683 \\
\hline 121 & Humans have a right to use animals as a food. & & & 0.419 \\
\hline & Eigenvalue (Total = 9.455) & 4.281 & 3.115 & 2.059 \\
\hline & Total variance explained $(\%)=49.767$ & 22.531 & 16.397 & 10.839 \\
\hline
\end{tabular}




\section{The findings for item analysis}

In this study, the item-total correlations for all items of scale were calculated to determine the relationship between a score on the item and a score on the test as a whole.
$\mathrm{KMO}$ value was found as 0.801 and also, the value for Bartlett's test of sphericity was found to be statistically significant $\left(x^{2}=1467.927, d f=171\right)$. Therefore, it can be said that the data were suitable for the factor analysis. After collecting all this evidence about the

Table 3. Overall goodness-of-fit in the ASTA

\begin{tabular}{lccc}
\hline \multicolumn{1}{c}{$\begin{array}{c}\text { Overall Goodness-of-Fit } \\
\text { Index }\end{array}$} & Criteria & $\begin{array}{c}\text { Application results } \\
\text { Absolute Fit Indices }\end{array}$ & $\begin{array}{c}\text { Evaluation } \\
\text { results }\end{array}$ \\
\hline Likelihood-ratio $X^{2}$ & $P>0.05$ & $395.13^{*}$ & Poor \\
df & - & 149 & - \\
GFI & $\geq 0.90$ & 0.84 & Poor \\
AGFI & $\geq 0.90$ & 0.79 & Poor \\
RMR & $\leq 0.08$ & 0.07 & Good \\
SRMR & $\leq 0.08$ & 0.08 & Acceptable \\
RMSEA & $\leq 0.08$ & 0.087 & Acceptable \\
NFI & Relative Fit Indices & & Poor \\
NNFI & $\geq 0.90$ & 0.85 & Acceptable \\
IFI & $\geq 0.90$ & 0.89 & Good \\
CFI & $\geq 0.90$ & 0.90 & Good \\
PGFI & $\geq 0.90$ & 0.90 & Good \\
PNFI & Parsimony Fit Indices & & Good \\
Likelihood-ratio $X^{2} / \mathrm{df}$ & $\geq 0.50$ & 0.66 & Good \\
\hline
\end{tabular}

Buyukozturk (7) stated that the item-total correlation is desired to be positive and even above 0.30 . Values greater than 0.30 indicate that the instrument has the desired reliability. It is suggested that values less than 0.30 should be removed. At the end of item-total analysis, 11 items $(14,117,118,119,120,124,125,127$, 128, 129 and 130 ), the adjusted item-total correlation values of which were under 0.30 were eliminated from scale and items in the scale reduced to 19 (Table 1).

As shown in Table 1, the item-total correlations of 19 items left in the scale were between 0.310 and 0.543 . According these findings, it can be said that these items measure similar behaviors and also have satisfactory discriminatory power.

\section{The findings for construct validity}

In this study, the factorial validity of the ASTA was tested via firstly Explanatory Factor Analysis (EFA) and then Confirmatory Analysis (CFA).

Explanatory factor analysis (EFA); EFA was performed with the 19 items in the ASTA. In prior to the factor analysis, the Kaiser-Meyer-Olkin (KMO) value was used in order to test the sufficiency of the sample and Bartlett's Sphericity value was used to examine the appropriateness of the data with the factor analysis (15). According to the analysis results, the suitability of the data set, factor analysis was performed on 19 items using the Principal Components factorization technique and Varimax rotation. The criteria for determining the number of factors to retain were eigenvalue greater than 1 and the scree-test (13) and also, a factor load value of 0.30 was taken into account to evaluate the suitability of items.

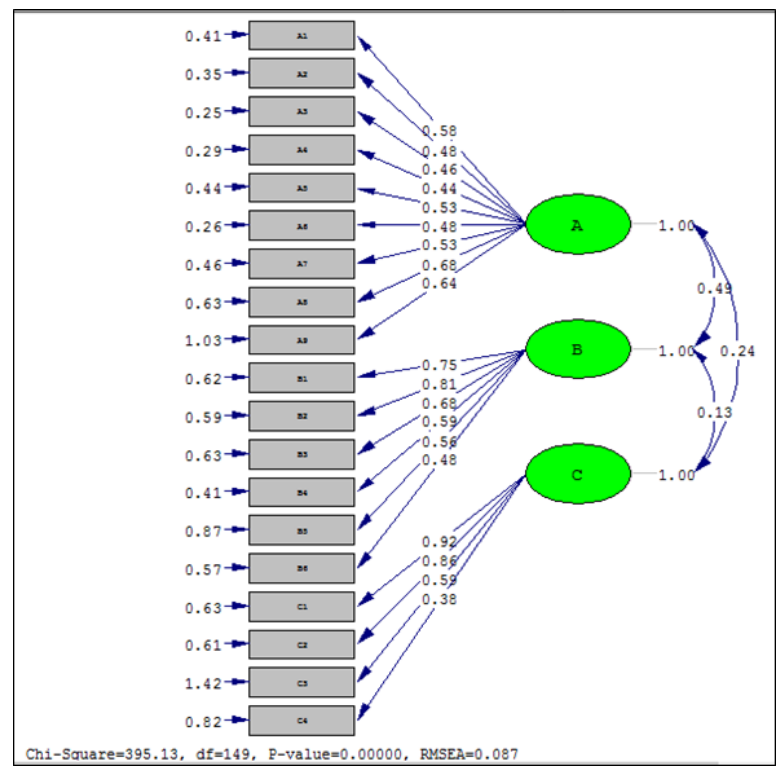

Figure 2. Path diagram of CFA 
The findings from the scree plot (Figure 1) and subsequent analysis (Table 2) indicated that all of the items in the scale had factor loadings greater than the lower limit of 0.30 . The findings from Table 2 also indicated that the scale had three factors with eigenvalues of 1 or higher.

As a result of EFA, no item was removed from the scale, and thus ASTA were constructed as three factors and 19 items. As shown in Table 2, the threefactor construct explained $49.767 \%$ of the total variance. The value of total variance between $40 \%$ and $60 \%$ is claimed to be sufficient for social science studies, and for any factor to be meaningful, at least $5 \%$ of the total variance explained should be attributable to that factor $(16,39)$. In addition, according to the EFA results in Table 2, the factor loadings of nine items related to the first factor "Pets" of the ASTA vary between 0.555 and 0.722 , and also explain $22.531 \%$ of the total variance. In the second factor, the factor loadings of six items related to the "Pests" factor of the ASTA vary between 0.589 and 0.758 while explaining $16.397 \%$ of the total variance. And finally, in the third factor, the factor loadings of four items related to the "Profit" factor of the ASTA vary between 0.419 and 0.829 while explaining $10.839 \%$ of the total variance.

Confirmatory factor analysis (CFA); In addition to Explanatory Factor Analysis (EFA), Confirmatory factor Analysis (CFA) was performed to confirm that the scale consisted of three factors. In confirmatory factor analysis, it is tested whether a model, which is produced on the basis of previously acquired data, will be confirmed by existing data (27). Path diagram and goodness of fit statistics were produced for the three-factor model with 19 items. In the analysis process, each factor and its items were coded. Therefore, the items in the first factor were coded as $A 1 \ldots$ $A 9$, as $B 1 \ldots B 6$ in the second factor and as $C 1 . . . C 4$ in the third factor. Figure 2 indicated that standardized factor loads between the items in the original scale and the constructs that items inclined to measure were found to be statistically significant according to $t$ test results and all factor loads (12).

Additionally, fit indices suggested by Seçer (35) and the findings from this study are summarized in Table 3.The fit values were found to be $x 2 / d f=2.65$, RMSEA $=0.087, \mathrm{RMR}=0.07, \mathrm{SRMR}=0.08, \mathrm{CFI}=0.90$, $\mathrm{NNFI}=0.89, \mathrm{NFI}=0.85$, and $\mathrm{IFI}=0.90$. In literature, an RMSEA in the range of 0.05 to 0.10 was considered an indication of fair fit and values above 0.10 indicated poor fit (25). Therefore, it was thought that 0.087 value of RMSEA in this study provides a mediocre fit. However, more recently, a cut-off value close to 0.06 or a stringent upper limit of 0.07 seems to be the general consensus amongst authorities in this area (19).

Additionally, Chi-Square statistic nearly always re- jects the model when large samples are used, and also, this statistic lacks power and therefore may not discriminate between good fitting models and poor fitting models when small samples are used $(19,20,21)$. Due to the restrictiveness of the Model Chi-Square, researchers have sought alternative indices such as relative/normed chi-square $(x 2 / d f)$. Therefore, $x^{2} / \mathrm{df}$ obtained from this study is an acceptable ratio for this statistic.

In this study, the values for GFI and AGFI in Table 3 seem poor. In relation to the low value of GFI, Sharma, Mukherjee, Kumar and Dillon (36) put forward that the GFI indicates a downward bias when there are a large number of degrees of freedom in comparison to sample size. Similarly, according to Hooper, Coughlan and Mullen (19), given the sensitivity of GFI index, it has become less popular in recent years and it has even been recommended that this index should not be used. And also, related to the GFI is the AGFI, which adjusts the GFI based upon degrees of freedom, with more saturated models reducing fit. Thus, more parsimonious models are preferred. On the other hand, NFI seemed to have poor value. A major drawback to this index is that it is sensitive to sample size, underestimating fit for samples less than 200 , and thus is not recommended to be solely relied on $(2,22)$. In conclusion, according to these values, CFA results indicated acceptable fit.

\section{Analysis of the scale's reliability}

In this study, Cronbach's Alpha coefficient of each factor was calculated to determine the internal consistency of the factors obtained from the ASTA. According to the findings, this value $(\alpha)$ was 0.848 for factor "Pet (A)", 0.798 for factor "Pest (B)" and 0.653 for factor "Profit (C)". In addition, Cronbach's Alpha for the overall scale was calculated as 0.827 . As stated by Özdamar (28), coefficients greater than 0.60 indicate good reliability in the scale and high consistency among the scale items. Therefore, it can be said that the findings revealed from the data set were also considerably reliable.

\section{Discussion and Conclusion}

In this study, Attitude Scale towards the Treatment of Animals [ASTA], which was originally developed by Taylor and Signal (41), was adapted to Turkish and also, its validity and reliability analyses were conducted. The original form of the scale included a 30 -item with three subscales namely Pet, Pest and Profit and was in English language. Therefore, the analysis for linguistic validity was firstly conducted to adapt the Attitude Scale towards the Treatment of Animals to Turkish. In this perspective, the translation was made by the researchers of this study and then presented the views of 4 experts in the field. After obtaining expert views, English and Turkish forms of the scale 
were applied to 24 students who were familiar with animals and other living organisms because of their field of study. The findings obtained from the students indicated there was a high correlation between the two applications $(r=0.808, \mathrm{P}<0.001)$ and thus, the translation was successful and obtained linguistic equivalents. After the linguistic equivalence of the scale was provided, the draft form of the scale was put into practice with pilot scheme (35) in which item analysis, construct validity (EFA and CFA) and finally analysis of Cronbach Alpha values were done.

The results from item analysis demonstrated that item-total correlations of 11 items in ASTA were not at desired levels $(P>0.30)$ and thus these items $(4,17$ $20,24,25,27-30$ ) were eliminated from the scale. The corrected item-total correlations of 19 items left in ASTA changed between 0.419 and 0.829 . These results indicated that the items distinguished the individuals sufficiently in terms of relevant features of the items (8). The construct validity of the scale was tested with EFA and CFA, respectively. The results of EFA indicated that ASTA was constructed as three factors and 19 items. The factors were named according to their items with higher factor loadings. Thus, the first factor was named as "Pets", the second factor was named as "Pest" and the third factor was named as "Profit". In addition, the findings from CFA indicated that the ASTA was at an acceptable degree of goodness of fit for Turkish university students. Finally, reliability analysis results indicated that reliability coefficient (Cronbach Alpha) for the overall scale was calculated as 0.827 , and, $0.848,0.798$ and 0.653 for the three sub-factors, respectively. According to these results, it can be said that the findings revealed from the data set were considerably reliable.

Based on the results of the study, the ASTA can be considered to be a valid and reliable tool for determining the university students' attitudes towards the treatment of animals. However, the fact that the ASTA had a construct with three sub-factors. This finding is similar to the results of the study by Taylor and Signal (41). In this study, 30 items of original scale, which included 19 items, were valid and reliable in Turkey and also these 19 items in the ASTA were found to measure the dimensions of the Pets, Pests and Profit in the original scale. Therefore, it can be said that the $4^{\text {th }}, 17^{\text {th }}, 18^{\text {th }}, 19^{\text {th }}, 20^{\text {th }}, 24^{\text {th }}, 25^{\text {th }}, 27^{\text {th }}$, $28^{\text {th }}, 29^{\text {th }}$ and $30^{\text {th }}$ items in original scale do not explain Turkish students' attitudes. This difference between original scale and the scale adapted to Turkish may be due to cultural differences.

As relating factor "Pets", 14 which means that I find my pet a source of emotional comfort (or would if I had one) did not adequately address this subdimension in terms of Turkish students. Although students are familiar with animals and other living organisms, most of them were never owned a pet in their life. Therefore, students may not thoroughly perceive the effect of pet on their emotional comfort. As relating factor "Pests", totally four items (17-20) were eliminated from ASTA. Despite the fact that six items left in ASTA includes in the statements about pest rights, the eliminated four items seems to be statements about directly killing of pests. Therefore, it can be said that factor "Pest" focus more on the basics of animal welfare and right in Turkish form of ASTA. Although most participants were non-owners, it can be thought that this finding is satisfactory in terms of animal rights. Similar to the findings of this study, a study by Daly and Morton (11) indicated that there was no difference in empathy levels between pet owners and non-owners. Finally, the findings obtained from factor "Profit" indicated that the students agree commercial use of animals for human benefit. This finding was proven by the four items $(21-23,26)$ left ASTA. However, it seems that the most items related to abuse of animal were eliminated from the scale. Maybe, this finding may be caused by belief systems underlying views on this topic. Briefly, the findings from this study suggests that the ASTA measures attitudes towards the factor "Pets" more than attitudes towards factors "Pests" and "Profit".

Arguably, attitudes towards the treatment of animals fall into three sub categories: pets, pests and profit. However, the different categories such as replacement of animals in science or laboratory work with animals can be added to this scale. In addition, because of the fact that ASTA is a valid and reliable tool, Turkish and English version of ASTA can be utilized in experimental researches. The ASTA can be also applied to the difference participations for testing its effectiveness in terms of different variables. Finally, the fact that this study was carried out in Ataturk University may be considered as a limitation. Therefore, it is suggested that this scale be applied to students in different universities and the results be compared with those of the current research and thus, further evaluation of the scale should be validated with different sample groups.

\section{References}

1. Beaton DE, Bombardier C, Guillemin F, Ferraz MB. Guidelines for the process of crosscultural adaptation of self-report measures. Spine 2000; 25(24): 3186-91.

2. Bentler PM. Comparative fit indexes in structural models. Psych Bul 1990; 107(2): 238-46.

3. Boztunç-Öztürk N, Şahin MG, Kelecioğlu H. A review of articles concerning scale adaptation in the field of education. Educ Sci 2015; 40(178): 123-37.

4. Broom DM. Evolution of pain. In Pain: Its Nature and Management in Man and Animals. Interna- 
tional Congress and Symposium Series. Soulsby L, Morton D. eds. In: Roy Soc Med 2001; 246: 17 25.

5. Broom DM. Animal welfare education: Development and prospects. J Vet Med Educ 2005; 32: 438-41.

6. Bryman A, Cramer D. Quantitative data analysis with SPSS release on for windows. First Edition. Philadelphia: Routledge 2001; pp. 96.

7. Buyukozturk Ş. Sosyal Bilimler İçin Veri Analizi EI Kitabı. Yedinci Baskı. Ankara: Pegem Akademi Yayınları 2007; s. 171.

8. Buyukozturk Ş, Akgün ÖE, Özkahveci Ö, Demirel F. The validity and reliability study of the Turkish version of the motivated strategies for learning questionnaire. KUYEB 2004; 4(2): 207-39.

9. Buyukozturk Ş, Kılıç-Çakmak E, Akgün ÖE, Karadeniz Ş, Demirel F. Bilimsel Araştırma Yöntemleri Onuncu Baskı. Ankara: Pegem Akademi Yayınları, 2011; s. 16-91.

10. Chiang WW, Liu CJ. Scale of academic emotion in science education: development and validation. Int J Sci Educ 2014; 36(6): 908-28.

11. Daly B, Morton LL. Children with pets do not show higher empathy: A challenge to current views. Anthrozoos 2003; 16(4): 298-314.

12. Demir Ö, Yurdugül $H$. The adaptation of the scale of attitude towards computer into Turkish for middle and secondary school students. Educ Sci 2014; 39(176): 247-56.

13. Field AP. Discovering Statistics Using SPSS: And Sex and Drugs and Rock ' $n$ ' Roll. Third Edition. London: Sage Publications 2009; pp. 640.

14. Fraser D, Duncan IJ. 'Pleasures','pains' and animal welfare: toward a natural history of affect. Anim Welfare 1998; 7(4): 383-96.

15. Güngören ÖC, Bektaş M, Öztürk E, Horzum MB. Acceptance of TPC scale - Validity and reliability study. Educ Sci 2014; 39(176): 69-79.

16. Gürer MD, Yıldırım Z. Development, validity and reliability study of the learning object evaluation scale. Educ Sci 2014; 39(176): 121-30.

17. Henry B. The relationship between animal cruelty, delinquency, and attitudes toward the treatment of animals. Soc Anim 2004; 12(3): 185-207.

18. Herzog H, Betchart N, Pittman R. Sex role identity and attitudes toward animals. Anthrozoos 1991; 4 (3): 184-92.
19. Hooper D, Coughlan J, Mullen M. Structural equation modelling: Guidelines for determining model fit. Electron J Bus Res Meth 2008; 6(1): 53-60.

20. Jöreskog K, Sörbom D. Lisrel 8: Structural equation modeling with the simplis command language. First Edition. Chicago: Scientific Software International 1993; p. 43.

21. Kenny DA, McCoach DB. Effect of the number of variables on measures of fit in structural equation modeling. Struc Equ Model 2003; 10(3): 333-51.

22. Kline RB. Principles and Practice of Structural Equation Modeling. Third Edition. New York: The Guilford Press 2011; pp. 12.

23. Lan YL. Development of an attitude scale to assess K-12 teachers' attitudes toward nanotechnology. Int J Sci Educ 2012; 34(8): 1189-210.

24. Mazas B, Fernández-Manzanal MR, Zarza FJ, María GA. Development and validation of a scale to assess students' attitude towards animal welfare. Int J Sci Educ 2013; 35(11): 1775-99.

25. MacCallum RC, Browne MW, Sugawara HM. Power analysis and determination of sample size for covariance structure modeling. Psychological Methods 1996; 1(2): 130-49.

26. McMillian JH, Schumacher S. Research in Education: Evidence-based Inquiry. Seventh Edition. Boston: Pearson 2010; pp. 22.

27. Melanlıoğlu D. Determining the psychometric features of reading anxiety scale. Educ Sci 2014; 39 (176): 95-105.

28. Özdamar K. Paket programlar ile istatistiksel veri analizi II. Beşinci Baskı. Eskişehir: Kaan Kitabevi 2004; s. 235.

29. Plous S. Attitudes toward the use of animals in psychological research and education: Results from a national survey of psychology majors. Psych Sci 1996; 7: 352-8.

30. Potaka L, Cochrane S. Developing bilingual questionnaires: Experiences from New Zealand in the development of the 2001 Mäori Language Survey. JOS 2004; 20(2): 289-300.

31. Regan T. The case for animal rights. Second Edition. Berkeley, CA: University of California Press 2004; pp. 15.

32. Rolston $\mathrm{H}$. The value of species. Regan $\mathrm{T}$, Singer $P$. eds. In: Animal rights and human obligations. Englewood Cliffs, NJ: Prentice Hall 1989; pp. 2525. 
33. Rowan AN, Loew EM, Veer JC. The animal research controversy: Protest. process \& publicpolicy: an analysis of strategic issues. North Grafton, MA: Tufts University, Center for Animals and Public Policy, 1995; s. 18.

34. Sandoe P, Crisp R, Holtug N, Ethics: Chapter 1. Appleby MC, Hughes OB. eds. In: Anim welfare. Wallingford: CABI Publishing 1997; pp. 3-17.

35. Seçer I. Adapting the child version of obsessivecompulsive inventory into Turkish: The study of reliability and validity. Educ Sci 2014; 39(176): 355-67.

36. Sharma S, Mukherjee S, Kumar A, Dillon WR. A simulation study to investigate the use of cutoff values for assessing model fit in covariance structure models. JBR 2005; 58(1): 935-43.

37. Singer P. All animals are equal. Regan T, Singer $P$. eds. In: Animal rights and human obligations Englewood Cliffs, NJ: Prentice Hall 1989; pp. 7386.

38. Tabachnick BG, Fidell LS. Using multivariate statistics. Fifth Edition. Boston: Pearson/A\&B 2007; s.26.

39. Tavşancıl E. Tutumların Ölçülmesi ve SPSS ile Veri Analizi. Dördüncü Baskı. Ankara: Nobel Yayın Dağıtım 2010; 46-50.

40. Taylor N, Signal, TD. Empathy and attitudes to animals. Anthrozoos 2005; 18(1): 18-27.

41. Taylor N, Signal TD. Pet, pest, profit: Isolating differences in attitudes towards the treatment of animals. Anthrozoos 2009; 22(2): 129-35.

42. Totan T, Yavuz Y. Westside sınav kaygısı ölçeğinin Türkçe formunun geçerlik ve güvenirlik çalısması. MAKU J Educ Fac 2009; 9(17), 95109.

43. Van der Weijden JA. Attitudes towards the use of animals of students enrolled in animal welfare and laboratory science courses in the Netherlands. Published Master Thesis. Utrecht University, Netherland 2013; pp. 1-22.

44. Wilson CC, Netting FE. The status of instrument development in the human-animal interaction field. Anthrozoos 2012; 25: 11-55. 
